УДК 9

DOI $10.21661 / \mathrm{r}-467694$

\title{
E.B. Старина
}

\section{КУКОЛЬНЫЙ ТЕАТР. ИСТОРИЯ И СОВРЕМЕННОСТЬ}

Аннотация: автор статьи делает попытку проследить этапы развития кукольного театра в контексте истории, а также, на основе личного опыта работы с детьми, выделить его воспитательное значение в области современной дошкольной педагогики. Данная работа может представлять интерес для педагогов дошкольного образования, занимающихся театральной деятельностью детей, педагогов дополнительного образования, а такэе руководителям театральных студий.

Ключевые слова: воспитательное воздействие, театральная педагогика, соииализаџия, художественный вкус.

\section{E.V. Starina}

\section{PUPPET THEATER. HISTORY AND MODERN TIMES}

Abstract: the author of the article makes an attempt to follow the stages of puppet theater development in the context of history, and on the basis of personal work experience with children. Also, he tries to highlight its educational significance in the field of modern pre-school pedagogy. This work may be of pre-school educators interest, engaged in theatrical activities of children, teachers of additional education, as well as directors of theater studios.

Keywords: educational impact, theatrical pedagogy, socialization, artistic taste.

$$
\begin{aligned}
& \text { Мир театра -мир волшебный, } \\
& \text { Для души - бальзам иелебный, } \\
& \text { Для ума - простор вселенной, } \\
& \text { Сердиу трепетному - дар, } \\
& \text { Счастлив в нем и млад, и стар! } \\
& \text { Е.В. Старина }
\end{aligned}
$$

Кукольный театр, как и любой другой вид искусства, имеет свою историю. Он пришел к нам из глубины веков. Известно, что первые куклы появились на 
заре развития человечества и были выполнены из дерева, камня, кости. Ученые историки и археологи утверждают, что языческие идолы, изображающие богов, были первыми куклами, а шаманы и жрецы - первыми актерами, режиссерами и кукловодами кукольного театра. Кукла была центральной фигурой в культовых, религиозных обрядах и праздничных действиях. История мировой культуры имеет сведения о существовании ритуальных мистерий с применением куклы в древнем Египте и Греции. Однако же истоки кукольного действа в России лежат в язычестве. Захватывая и чаруя человека своей самобытностью, кукла влекла его в мир волшебства, таинства. Под музыку национальных инструментов или пение уводила она человека от трудностей и обыденности реальной жизни.

Менялись эпохи, развивалось человечество, но куклы по-прежнему играли значительную роль в жизни народов разных стран. Однако ни в одной стране Европы и Азии кукольного театра, как отдельного вида искусства не существовало, поскольку определение «Театр» трактуется историками и искусствоведами как учреждение, предприятие, имеющее отдельное помещение для показа спектаклей и наличие постоянного состава актеров. Однако, это утверждение не исключает существование бродячих групп и одиночных кукольников. Так, перемещаясь по разным странам, актеры-кукольники несли определенную культуру в народные массы. Зачастую лицедейство кукольников противоречило законам правопорядка, (поскольку высмеивало пороки общества и власть имущих) поэтому приравнивалось к нищенству, шарлатанству, крамоле, и, как социально опасное явление, подвергалось гонению со стороны властей. Так, например, в Москве в Сокольническом парке, кукольные представления разрешались лишь по воскресеньям и в ярморочные дни. Стражи порядка строго следили за содержанием выступлений, нещадно наказывали любое проявление инакомыслия.

Несмотря на различие языков, обычаев и традиций у всех кукольников было много общего: все они пользовались переносной ширмой и перчаточной куклой. В Англии эту куклу называли Панч, в Германии - Касперле, во Франции - Полишинель, а в России - Петр Иванович Уксусов или попросту Петрушка. Именно 
он, Петрушка пользовался особой любовью и симпатией русского народа и благополучно дожил до наших дней.

Неужели знать и образованные граждане на самом деле так не любили кукольные представления? Любили, да еще как! Просто статус не позволял признаться, что их утонченность и просвещенность несовместима с проявлением интереса к плебейскому, недостойному виду театра, каким они считали кукольные выступления. Как альтернатива балаганному кукольному лицедейству в 1733 году по приглашению Анны Иоановны в Москву и Петербург прибыли итальянские комедианты и основали четыре театра кукол. Так государственным чиновникам стало проще контролировать и предотвращать нежелательное воздействие на умы и настроения народа, тем более, что посещение театров была прерогатива богатых слоев общества. Кроме этого, в восемнадцатом веке, дабы оттеснить балаганное искусство, прочно в моду вошли шарманки с движущимися фигурками, музыкальные табакерки, часы с открывающимися створками. Это было примитивно, но очень изящно и модно. В России такая европейская мода хотя и имела место быть, однако ей не удалось заменить собой живую энергию кукольных представлений. Правилами хорошего тона стало считаться в дворянских семьях устраивать кукольные спектакли для детей на Рождество или дни рождения детей, подтверждение тому мы находим в многочисленных художественных произведениях, эссе и воспоминаниях известных людей того времени.

«Светлой радостью детства» называл М.Ю. Лермонтов свой домашний театр марионеток. Из воспоминаний современников, великого поэта, мы узнаем о том, что в детстве он был увлечен изготовлением марионеток. Движение слонов, фигурок воинов, приводило его в восторг и порождало желание сочинять сюжеты баталий, которые он тут же разыгрывал перед зрителями.

Приведенный пример - не единственное свидетельство увлечения кукольным театром светских семей российского общества. Домашний кукольный театр положил начало массовому искусству. И мы смело можем сказать, что кукольный театр, как вид театрального искусства, пройдя все невзгоды, прочно занял свое законное место, успешно живет и процветает в наши дни. 
Первый в мире детский театр был построен в Москве в 1918 году под руководством Натальи Сац. В нем ставились спектакли с использованием кукол различных систем (напольные, штоковые, би-ба-бо, марионетки и др.) Затем детские театры стали появляться и в других крупных городах.

Так, сразу после Октябрьской революции открылся первый профессиональный кукольный театр в Петрограде. В ту пору он назывался Петроградский государственный театр Марионеток, в дальнейшем стал носить имя его создателя Е.С. Деммини. Вскоре последовало еще одно открытие кукольного театра. Это был «Большой Театр кукол», в 1935 году открылся Театр Юного Зрителя им. Брянцева, где так же давались кукольные представления.

Детские театры того времени являли собой некий общественный институт педагогического воздействия на личность ребенка и находились под патронатом государства. Подтверждением является тот факт, что руководство ими осуществлялось народным комиссариатом, а не министерством культуры.

В каждом театре непременным было наличие педагогической части, которая коллегиально определяла репертуарную политику и требовала от всех работников театра, включая декораторов, художников, оформителей и других сотрудников, педагогического мышления. Благодаря такому государственному подходу, наша страна приобрела уникальный опыт в области театральной педагогики. И поныне, следуя лучшим традициям театрального искусства, кукольный театр в современной России занимает достойное место в системе дошкольного образования и используется как действенный инструмент в воспитании личности, формировании нравственного и эстетического мировоззрения.

Участие в коллективном действии ведет к успешной социализации ребенка, позволяет раскрыть творческие способности, избавиться от излишней робости, или, напротив, несдержанности и агрессивности, повышает границы самооценки, развивает способность к перевоплощению.

Создавая студию, мы взяли ориентир на кукольные постановки спектаклей. От сюда и название студии: «Кукляндия», такой подход обусловлен тем, что, что кукла с рождения близка ребенку. Она может творить чудеса: развеселить, 
научить сопереживать, быть доверенным лицом (ей можно пожаловаться). Одним словом, кукла - друг. И отношение к ней у ребенка трогательное. Он чувствует себя волшебником, способным оживить театральную куклу, поскольку без него кукла всего лишь бездушный маленький предмет. Ребенок наделяет ее различными человеческими качествами, его голосом кукла разговаривает, по его воле совершает разные поступки и действия, он для театральной куклы - опекун и защитник. В нашей студии мы учим детей относиться к куклам, как к живым существам. Например, приходя в студию, дети здороваются с куклами, а уходя говорят: «Не скучай, наша Кукляндия», мы скоро придем!».

Наша студия молода, (на данный момент ей три с половиной года) но за это время многое сделано: есть отдельные помещения, которые необходимы для работы и показа спектаклей, стационарные и переносные ширмы, наборы кукол для пальчикового, магнитного, плоскостного, настольного театров. Большую часть кукол изготовлена своими руками, что особо ценно. Как показала практика, самодельные куклы марионетки, тростевые, платковые, напольные, «живая рука» и др. очень самобытны, оригинальны, наделены собственным характером. Они пользуются большим спросом и используются нами в авторских постановках. Такого кукольного материала у нас накопилось на целую коллекцию, поэтому, нами планируется создание Музея театральной куклы, сделанной своими руками.

Создание собственных авторских спектаклей тоже занимает большое место в работе. Необходимость в них обусловлена желанием быть в общей канве педагогических задач, стоящих перед ДОУ. Так, например, в рамках Проекта Дружбы и толерантности народов России и ближнего зарубежья, нами было создано театрализованное представление «Сказка седого Байкала» по мотивам бурятских сказок.

Театральная студия в детском саду - это не школа театрального мастерства, а инструмент позволяющий использовать средства театра в целях воспитания художественного вкуса, лучшего понимания окружающего мира. 
Главное - создать между детьми и взрослыми доброжелательную атмосферу, основанную на понимании, уверенности, что тебе помогут справиться с определенными проблемами, порадуются твоим успехам.

Для успешной работы необходимо соблюдение основного принципа педагогики: от простого - к сложному. В этом контексте нами была разработана Программа, название которой говорит само за себя «От этюда - к спектаклю».

Работая по данной программе, мы стараемся всесторонне учитывать возможности детей, на первое место ставим уважение их интересов, любых творческих и индивидуальных проявлений, а также способствуем развитию общей культуры посредством театрализованной деятельности.

Курс Программы рассчитан на три года обучения начиная со средней и заканчивая подготовительной группой.

Результатом такой планомерной работы стало то, что дети к концу обучения способны, в качестве актеров, составлять диалоги между выбранными персонажами, при этом, эмоционально, образно и выразительно раскрыть характер героев, в качестве зрителей, способны дать объективную оценку действиям своих товарищей, отметить наиболее удачную трактовку образа.

В течение учебного года дети каждой возрастной группы дают три, четыре спектакля. Эти выступления всегда вызывают интерес у зрителей младшего возраста, а также одобрение и похвалу со стороны родителей.

Сцена мобилизует детей, повышает степень личной ответственности за общее дело, и, как следствие, выходя к зрителям, они демонстрируют свои лучшие актерские качества, а также приобретенные навыки кукловождения. Присутствие зрителей всегда вдохновляет, позволяет почувствовать «вкус славы, а следовательно, стимулирует желание совершенствовать мастерство.

Выпуская детей в школу, мы с удовлетворением отмечаем, что наш труд не был напрасен. Прекрасное зерно любви к театру, дало хорошие всходы. Мы уверенны, что, пойдя каждый своей дорогой, дети сумеют сориентироваться в жизненных ситуациях, найти правильный выход из трудного положения, отличить прекрасное от дурного и стать достойными людьми. 


\section{Список литературы}

1. Агапова И.А. Театральные занятия и игры в детском саду / И.А. Агапова, М.А. Давыдова. - М.: Аркти, 2010.

2. Гончарова О.В. Театральная палитра: Программа художественно-эстетического воспитания / О.В. Гончарова [и др.]. - М.: Сфера, 2010.

3. Доронова Т.Н. Театрализованная деятельность как средство развития детей 4-6 лет: Учебно-методическое пособие. - М.: Обруч, 2014.

4. Играем в театр. Театрализованная деятельность детей 4-6 лет. - М.: Просвещение, 2005.

5. Лаптева Г.В. Игры для развития эмоций и творческих способностей детей 5-9 лет. - СПб.: Речь, 2011.

6. Шорыгина Т.А. Беседы о характере и чувствах: Методические рекомендации. - М.: Сфера, 2013.

\section{References}

1. Agapova, I. A., \& Davydova, M. A. (2010). Teatral'nye zaniatiia i igry v detskom sadu. M.: Arkti.

2. Goncharova, O. V. (2010). Teatral'naia palitra: Programma khudozhestvennoesteticheskogo vospitaniia. M.: Sfera.

3. Doronova, T. N. (2014). Teatralizovannaia deiatel'nost' kak sredstvo razvitiia detei 4-6 let: Uchebno-metodicheskoe posobie. M.: Obruch.

4. (2005). Igraem $\mathrm{v}$ teatr. Teatralizovannaia deiatel'nost' detei 4-6 let. M.: Prosveshchenie.

5. Lapteva, G. V. (2011). Igry dlia razvitiia emotsii i tvorcheskikh sposobnostei detei $5-9$ let. SPb.: Rech'.

6. Shorygina, T. A. (2013). Besedy o kharaktere i chuvstvakh: Metodicheskie rekomendatsii. M.: Sfera.

Старина Евгения Валентиновна - педагог дополнительного образования ГБДОУ Д/С №62 Приморского района Санкт-Петербурга, Россия, Санкт-Петербург.

Starina Evgenia Valentinovna - preschool teacher at the state funded pre-school educational institution kindergarden № 62 of Primorsky district of St. Petersburg, Russia, St. Petersburg. 